\title{
Dynamic Relationship among Gold Price, Crude Oil Price, Rupiah Exchange Rate and Gross Domestic Product (GDP) in Indonesia during 1999-2018 with Phase-Wise Analysis

\author{
Sandy Kusnadi ${ }^{1}$, Ferdinand Dehoutman Saragih ${ }^{2}$
}

E-mail: Sandy.kusnadi@ui.ac.id ${ }^{1}$, saragih_fds@yahoo.com²

Department of Business Administrative, Faculty of Administrative Science, Universitas Indonesia, Depok, 16424, Indonesia

\begin{abstract}
Gold and crude oil are ones of the most strategic commodities claimed to have an influence on national economic movements. It is assumed that the two commodities have a relationship with foreign exchange rates. Foreign currencies, particularly US Dollar, greatly influence the economic and investment climate both nationally and internationally. This research aims to analyze the cointegration and causality relationship between the price of gold, the price of crude oil, the exchange rate of Rupiah, and the Gross Domestic Product (GDP) in 1999-2018. This research is quantitative research using data for 20 years starting from 1999 to 2018. The data in this study are time series data using quarterly data from 1999 to 2018 . The analysis technique used includes testing the Augmented Dickey-Fuller Test, Lag Optimum, Johansen Cointegration Test, Vector Error Correction Model (VECM), and VEC Granger Causality / Block Exogeneity Wald Test. The results of this study indicate that the variable price of gold, crude oil prices, the exchange rate of Rupiah, and Gross Domestic Product (GDP) has a cointegration relationship and the variable price of gold has a causal relationship with crude oil prices and the Rupiah exchange rate. In addition, there is also a causality relationship on Gross Domestic Product (GDP) to the price of gold.
\end{abstract}

Keywords: Macroeconomics Variable, Cointegration, Causality, VECM

\section{Introduction}

In the last recent years, there is fairly high uncertainty in global economy due to various macroeconomic factors affecting the rate of inflation in a country. Currently, global economy is undergoing a recovery process supported by already improving economic performance, a recovery momentum for the decline in economic growth into $3.8 \%$ in the fourth quarter of the last 2017 compared to the previous quarter of $3.9 \%$. The improvement is supported by the strengthening of economy in the United States, sustained by improving investment and consumption as well as fiscal stimulus. Meanwhile, developing countries such as Brazil and Russia are able to escape economic recession since they are the drivers of economic growth.

In contrast to the improving economic performance in the United States, other developed countries experience internal and external pressures. Japan, for example, experiences a moderate decline caused by weakened export yet strengthened import. Slow production activities and the increasing oil price are assumed to induce the decline. Furthermore, economic performance in developing countries has generally declined due to the improvement in a number of major countries. The economy of China is expected to be stable at a fairly high level, encouraged by an increase in consumption, where investment declines in line with the rebalancing of economy. The commodities with a fairly high level of consumption are crude oil and gold. Other factors considered as non-fundamental factors include infrastructure, geopolitics and speculation. In addition, crude oil price is frequently associated with inflation, while gold is considered as a hedge against inflation.

Another most traded commodity is gold. Since a long time ago, gold has been considered as the most valuable metal [1]. Furthermore, gold has been considered as a significantly conservative investment due to its scarcity. In investment sector, the demand for gold is generally utilized for portfolio investment tools [2]. In the last three decades, the annual volume of gold has tended to increase by approximately $235 \%$. Investors utilize gold as a function of storing wealth, an investment, and a form [3]. The gold market has attracted numerous investors since gold also functions as a hedge. Gold is an investment to protect values against inflation, politics and currency risk; stock market returns; and portfolio diversification [3].

In addition to the two aforementioned commodities, exchange rate is one of the main determinants of the relative level of economic health of a country. Exchange rate plays an important role in the level of trade, highly essential for every free market economy in the world. Fluctuation in exchange rate shall affect economic activity in both real and financial sector. Exchange rate movements shall affect trade relations of a country with other countries when a higher-value currency renders imports less expensive and exports more expensive in foreign markets or otherwise. While a higher exchange rate tends to deteriorate the balance of trade, a lower exchange rate is expected to improve it. Exchange rate is also utilized as an indicator of financial conditions and a determining factor in the global and local economy [4]. 
Indonesia is a country with great economic potential that is acknowledged globally. In recent years, the central government of Indonesia has begun to restrict export commodities (particularly raw material commodities) while increasing the role of the manufacturing industry. This restriction on exportation, however, provides difficulties for investors or private sectors to invest. This restriction exacerbates the already weakened export performance of Indonesia, reducing state revenue from foreign exchange and diminishing purchasing power, ultimately leading to an economic slowdown.

As the most traded commodities, crude oil and gold are utilized as the indicators of economy. Crude oil price is frequently associated with inflation, while gold is considered as a hedge against inflation. Meanwhile, the exchange rate of US Dollar to Rupiah is the standard currency in conducting international trade. The process of finalizing the commodity, oil, gold, US Dollar, and stock markets share diversified nature and statistical properties with other general characteristics [5]. According to numerous economists conducting studies on macro economy, fluctuating macroeconomic variables shall correlate with other variables [2].

In regard to the aforementioned description, this study aims to analyze the cointegration and causality relationship among gold price, crude oil price, Rupiah exchange rate, and GDP. It is expected that the findings of this study are able to be utilized by investors as considerations for investment decisions and by governments to intervene in maintaining currency values and implement monetary policy such as currency depreciation.

\section{Literature Review}

A study conducted entitled "Phase-wise Analysis of Dynamic Relationship among Gold, Crude Oil, US Dollar and Stock Market" examined the periods of pre-crisis (from June 6, 2005 to August 31, 2008), crisis (from September 1, 2008 to December 31, 2010), and post-crisis (from January 1, 2011 to December 31, 2016) in India [3]. This study employed five methods of econometric analysis, namely the Augmented Dickey-Fuller Test for Unit Root, Johansen Cointegration Test, Vector Error Correction Model (VECM), Vector Auto Regression (VAR), VEC Granger Causality/Block Exogeneity Wald Test, and Toda-Yamamoto modified Granger causality. The findings revealed that all four variables (gold, crude oil, US dollar, and stock market) have a dynamic nature throughout the three periods of global financial crisis.

Conducted a study entitled "Analysis of Cointegration and Causality Relationship between Gold Prices, World Oil Prices, the Rupiah Exchange Rate, and the Composite Share Price Index (CSPI) for the 2007-2016 Period" in Indonesia [6]. This study applied time series method, such as the Augmented Dickey-Fuller Test for Unit Root, Granger Causality Test, Johansen Cointegration Test, Vector Auto Regression (VAR), Variance Decomposition Test, and Impulse Response Analysis. The findings indicated that there is no cointegration relationship between gold price, world oil price, rupiah exchange rate and CSPI, yet world oil price and CSPI have a causal relationship with rupiah exchange rate.

Conducted a study entitled "The Relationship of Oil Prices, Gold Prices, Gross Domestic Product, and Interest Rates to the Stock Market Return of Basic Industry and Chemical Sector in Indonesia in 2005-2013" in Indonesia. This study utilized classical assumption test, Multiple Linear Regression, Coefficient Determination Analysis, and Hypothesis testing using F-test and T-test [6]. The findings revealed that several variables significantly influence stock market return, one variable does not have a significant effect on stock market return, and one variable must be omitted.

Conducted a study entitled "Oil, Gold, US Dollar and Stock Market Interdependencies: a Global Analytical Insight" using data from January 1995 to October 2015, employing simultaneous approach. This study aims to identify both direct and indirect relationship regarding the interdependencies of all markets including gold, oil, US Dollar and stock market in a global perspective [5]. The findings revealed no direct effect on the presence of global banks, global dependencies, and the process of finalizing the commodity market. Thus, it can be concluded that there is a significant change in the relationship among the four variables. No long-term causality is discovered, while short-term causality is reported in several cases.

\section{Research Method}

This study employed a quantitative approach and utilized quarterly data and time series data with a total sample of 80 observations over the period 1999-2018. The data on gold price are obtained from the World Gold Council, crude oil price from the US Energy Information Administration and monthly data from West Texas Intermediate, exchange rate from Bank Indonesia, and GDP from the Ministry of Trade of the Republic of Indonesia and the Central Bureau of Statistics (BPS). Meanwhile, the econometric analysis utilized E-views 9.

This section shall discuss the techniques and tools employed in this study. Descriptive statistical analysis and Augmented Dickey-Fuller Test were employed firsthand, aiming to test the stationarity of the variables in the 
study. Afterwards, Johansen's cointegration approach was utilized to study the long-term relationship between variables. Should a variable is cointegrated, the Vector Error Correction Model (VECM) was applied next. Should it is not, Vector Auto Regression (VAR) model was applied instead. The final techniques were Granger/Wald VEC causality test and the Toda Yamamoto (TY) modified Granger causality, employed to analyze short-term causality among variables.

\section{a. Augmented Dickey-Fuller Test}

Testing the stationarity of the data is necessary in a study utilizing time series data, called stationary stochastic process. This test aims to avoid spurious regression. Test of stationarity is conducted by "increasing" the previous three equations by adding the lag value of the dependent variable $\Delta \mathrm{Yt}[8][9][9,10]$. Three equations in the test of stationarity include mean, variance, and autocovariance [7]. Stationary data is data that has the same probability distribution pattern. If calculated at different times will cause the same pattern. Meanwhile, for nonstationary data will show a different pattern and move away from the starting point of the period. ADF test is one of the most widely used methods to test the stationarity of variables in time series data [3]. The following is the regression model of Augmented Dickey Fuller Test formulated [3]:

b. Johansen Cointegration Test

$$
\Delta Y_{t}=\beta_{1}+\beta_{2} t+\delta Y_{t-1} \sum_{i=1}^{m} \alpha \Delta Y_{t-1}+\varepsilon_{t}
$$

This method is considered as a multivariable generalization of the Augmented Dickey-Fuller Test method. The generalization includes the test of linear combinations of variables for unit root. Johansen Cointegration Test provides an estimate of all cointegration vectors. The following is the $k$ th equation of VAR model used to test the Johansen Cointegration Test, quoted from Singh and Sharma (2018):

$$
\Delta Y_{t}=\mu+\Pi Y_{t-1} \sum_{i=1}^{k-1} \Gamma_{i} Y_{t-1}+\varepsilon_{t}
$$

c. Vector Error Correction Model (VECM) and Vector Auto Regression (VAR)

Vector Error Correction Model (VECM) is used when the variables in a vector are non-stationary and have at least one or more cointegration relationships between variables. According to Engle and Granger (1987), VECM is used to find disequilibrium and the speed of adjustment to towards long-run equilibrium. The following is the equation of the Vector Error Correction Model (VECM) from Singh Sharma (2018):

$$
\Delta Y_{t}=\alpha+\beta \mathrm{ECT}_{t-1}+\sum_{i=1}^{k} \alpha_{i} \Delta Y_{t-1}+\sum_{i=1}^{k} \beta_{i} \Delta X_{t-1}+\varepsilon_{t}
$$

Meanwhile, the Vector Autoregressive (VAR) model is a special form of simultaneous equations. The VAR model may be applied should all variables are stationary. The VECM model is considered an appropriate strategy for cointegrated variables in long-term estimation since the VAR model does not explicitly consider long-term relationships [9]. The following is the equation of the Vector Autoregressive (VAR) model with $k$ lags [3]:

$$
\begin{aligned}
& Y_{t}=\beta_{10}++\sum_{i=1}^{k} \beta_{1 i} Y_{t-1}+\sum_{i=1}^{k} \alpha_{1 i} X_{t-1}+\varepsilon_{1 t} \\
& X_{t}=\beta_{20}++\sum_{i=1}^{k} \beta_{2 i} Y_{t-1}+\sum_{i=1}^{k} \alpha_{2 i} X_{t-1}+\varepsilon_{2 t}
\end{aligned}
$$

\section{d. VEC Granger Causality/Block Exogeneity Wald Test}

Causality test in this study aims to determine the causal relationship between two variables. This study employed Granger Causality Test method popularized by Engel and Granger in 1987. Granger Causality implies merely the relationship between the present value of one variable and the past value of another, meaning that the movement of one variable does not always cause the movement of another [12]. The following is the $k$ th bi-variate equation used for the VEC test [3]:

$$
\begin{aligned}
& Y_{t}=\alpha_{0}+\sum_{i=1}^{k} \alpha_{i} Y_{t-1}+\sum_{j=1}^{k} \beta_{j} X_{t-j}+\epsilon_{t} \\
& X_{t}=\gamma_{0}+\sum_{i=1}^{k} \gamma_{i} X_{t-1}+\sum_{i=1}^{k} \delta_{j} Y_{t-j}+\epsilon^{\prime}{ }_{t}
\end{aligned}
$$

There are two ways to employ Granger Causality Test. Should the given series is not cointegrated, the Granger test (1969) can be applied to study short-term relationships. However, this test does not apply should the given series is cointegrated. In such cases, the error correction VEC Granger Causality/Wald test is applied to analyze short-term causality.

e. Toda Yamamoto modified Granger Causality

Toda Yamamoto modified Granger Causality is different from Granger Causality since it does not require pre-testing [3]. Toda-Yamamoto modified Granger Causality test aims to determine the order of integration and whether the variables are cointegrated or not. This test is free from potential biases associated with unit root and cointegration test [10]. By applying Toda Yamamoto modified Granger Causality test, this study shall obtain a better insight into the causal relationship between these variables and the direction of causality. The following is the equation from Toda Yamamoto modified Granger Causality quoted from Singh and Sharma (2018):

$$
\begin{aligned}
& Y_{t}=\alpha_{0}+\sum_{i=1}^{k} \alpha_{1 i} Y_{t-i}+\sum_{j=k+1}^{d \max } \alpha_{2 j} Y_{t-j}+\sum_{i=1}^{k} \beta_{1 i} X_{t-i}+\sum_{j=k+1}^{d \max } \beta_{2 j} X_{t-j}+\epsilon_{1 t} \\
& X_{t}=\gamma_{0}+\sum_{i=1}^{k} \gamma_{1 i} X_{t-i}+\sum_{j=k+1}^{d \max } \gamma_{2 j} X_{t-j}+\sum_{i=1}^{k} \delta_{1 i} Y_{t-i}+\sum_{j=k+1}^{d \max } \delta_{2 j} Y_{t-j}+\epsilon_{2 t}
\end{aligned}
$$

Compared to the order of $k$ equation of VAR system in Granger Causality, the TY VAR system has an additional number of dmax delay requirements [4]. 


\section{Analysis}

a. Descriptive statistics and correlation analysis

The results of the descriptive statistical analysis using 80 observations on the variables of gold, crude oil, rupiah exchange rate, and GDP are illustrated as follows. This descriptive statistical analysis is conducted by analyzing mean, median, maximum value, minimum value, standard deviation as well as skewness and kurtosis. The following are the results of the descriptive statistical analysis for the period 1999-2018:

Table 1. Descriptive Statistical Analysis for the period 1999-2018

\begin{tabular}{|l|c|c|c|c|}
\hline & GOLD & OIL & KURS & PDB \\
\hline Mean & 881.864 & 59.96375 & 10325.24 & 1583806 \\
\hline Median & 934.970 & 58.60000 & 9448.000 & 1321391 \\
\hline Maximum & 1770.000 & 133.9300 & 14901.50 & 3841755 \\
\hline Minimum & 261.3100 & 14.66000 & 6705.000 & 271595.5 \\
\hline Std. Dev & 474.1752 & 27.72053 & 1983.007 & 1103650 \\
\hline Skewness & 0.076211 & 0.379522 & 0.778974 & 0.480063 \\
\hline Kurtosis & 1.613660 & 2.195366 & 2.468405 & 1.880970 \\
\hline & & & & \\
\hline Jarque-Bera & 6.483903 & 4.078611 & 9.032645 & 7.246896 \\
\hline Probability & 0.039088 & 0.130119 & 0.010929 & 0.026690 \\
\hline & & & & \\
\hline Sum & 70549.12 & 4797.100 & 826019.5 & $1.27 \mathrm{E}+08$ \\
\hline Sum Sq. Dev. & 17762527 & 60705.81 & $3.11 \mathrm{E}+08$ & $9.26 \mathrm{E}+13$ \\
\hline \multicolumn{2}{|c|}{} & & & 80 \\
\hline Observation & 80 & 80 & 80 & \\
\hline
\end{tabular}

Source: E-views 9

Referring to table 1 , the value of skewness of gold is 0.076211 , indicating that the distribution of gold is concentrated on the left side. However, as the value is close to 0 , it can be concluded that the data are almost symmetrically distributed. The value of skewness of crude oil is 0.379522 , indicating that the distribution of crude oil is concentrated on the left side. Similarly, the skewness of exchange rate and GDP is 0.778974 and 0.480063 respectively, indicating that their distribution is concentrated on the left side. The value of kurtosis of gold is 1.61366. Since the value is less than 3, the data is in the shape of platykurtic distribution. Similar to gold, other variables, namely crude oil, exchange rate, and GDP, also display a value of kurtosis of less than 3. In conclusion, all variables in this study are in the shape of platykurtic distribution.

Coefficient variation $(\mathrm{CV})$ is required to determine the level of volatility or risk in each variable, obtained by comparing standard deviation with mean. The following is the CV of each variable, namely $53.77 \%$ (gold), 46.23\% (crude oil), 19.21\% (Rupiah exchange rate), and 69.68\% (GDP). Rupiah exchange rate has the lowest $\mathrm{CV}$, meaning that Rupiah exchange rate has the lowest risk compared to other variables. The findings imply that all variables in the study, namely gold, crude oil, Rupiah exchange rate and GDP, have a high level of data diversity.

b. Augmented Dickey-Fuller Test for Unit Root

Observed from the results of stationarity test using the Augmented Dickey-Fuller Test, all variables in this study are stationary and do not have unit root (at the level of the 2nd Differences). The result of the first ADF Test at level stating gold with a value of -1.070597 , crude oil with a value of -1.657861 , an exchange rate with a value of -2.359954 , and GDP with a value of -2.202291 . Based on the test results indicate that all variables are nonstationary and have unit root. They are non-stationary since their probability values are more than 0.05 . Thus, tests are required until the data are stationary and do not have unit root. The next test is conducted at the $1^{\text {st }}$ Differences, revealing that GDP is the only non-stationary variable with a unit root. This is evidenced by gold with a value of $-9,145270$, crude oil with a value of $-8,287157$, an exchange rate with a value of $-11,02063, \&$ GDP with a value -1.903501 . Of the four variables, only the GDP variable still has a unit root and is categorized as not stationary. Therefore, the ADF Test at the $2^{\text {nd }}$ Differences is merely conducted on GDP. The result revealed that GDP is stationary and no longer have a unit root as the test generates a value of -8.051899 . The result of the ADF statistical test on GDP is smaller than that of the critical lag test 12 at the level of $1 \%, 5 \%$, and $10 \%$. In addition, the probability value of GDP is only 0.0000 which means that the probability value of GDP is less than 0.05 . So that the GDP variable can be categorized as a variable that does not have a root unit and is stationary.

c. Johansen Cointegration Test

Referring to the results of the ADF test, the Johansen Cointegration test is applicable for all variables. Prior to conducting the Johansen Cointegration Test, it is necessary to determine the optimum lag length by performing 
the optimum lag test. The determination of the optimum lag is shown to eliminate the autocorrelation problem in the VAR system because the lag in endogenous variables in the equation system will be used as an exogenous variable. Based on the results of the optimum lag test produces several values including LR which are 105,6515, FPE which is $2,89 \mathrm{E}+20$, AIC which is worth 58,45033, SC which worth 60,06940, and HQ which is worth 59,09620 . Because all five methods are in lag 3, so lag 3 was chosen to be the optimum lag in this study. In addition, selection of lag 3 is based on the number of criterion indicator selection, in which the most dominant shall be the benchmark. AIC is utilized as the benchmark since it is the most commonly used method in determining the lag length. Gujarati (2004) states that the lowest AIC value obtained from the estimation of VAR with various lags indicates the most effective lag length to utilize. Furthermore, the lag length is influential when using the Granger causality method and VAR estimation. Thus, the optimum lag of this study, serving as the basis for further testing, is at lag 3. The Johansen Cointegration Test shall be conducted afterwards.

The cointegration test is useful to discover long-term relationship by analyzing whether there are similarities in the movement and stability of the variables tested. Should cointegration is discovered, VAR test needs to be conducted using the restricted VAR or VECM method. However, should no cointegration is discovered, VAR test is the only test to conduct. The following are the results of the cointegration test based on the method by Johansen:

Table 2. Johansen Cointegration Test

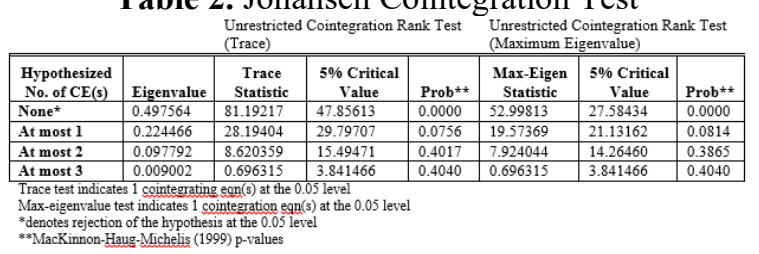

Source: Eviews 9

Based on table 2, the probability value generated from cointegration test using trace statistic is smaller than the critical value, evident from the probability value at none level or 0.0000 while the critical value is 0.05 or $5 \%$. It proves that there is merely one cointegration relationship among the variables of this study. Thus, this study positions gold as the dependent variable and the other three macroeconomic variables as independent variables. Due to the presence of that one cointegration relationship, the model that shall be employed afterwards is restricted VAR, or known as the Vector Error Correction Model (VECM).

d. Vector Error Correction Model (VECM)

Based on several results of previous tests, the variables in this study have a cointegration relationship between each variable. Thus, VECM shall be employed to the test data with cointegration. The VECM test shall explain the long-term cointegration relationship or error correction term as well as the short-term effect. As previously mentioned, the lag is at lag 3 when all variables are stationary. Thus, the lag shall increase by $t+1$ since VECM test utilizes non-stationary data.

Based on VECM test results, there is a short-term cointegration relationship at a certain lag between each variable of the study. As macro economy and gold are variables observed in previous studies, this study applied VECM. The VECM reveals that GDP is the only variable with a short-term positive relationship with gold while oil and exchange rate have a short-term negative relationship with gold. It indicates that the long-term effect of macro economy explained in the short-term cointegration model shall be equal. The difference is discovered in the lags in the short-term relationship between macro economy and gold. In the $2^{\text {nd }}, 3^{\text {rd }}$ and $4^{\text {th }}$ lag, the short-term relationship between macro economy and gold has shifted. This, perhaps, is caused by the need to adjust information related to the changes of the variables of macro economy towards gold.

e. VEC Granger Causality/Block Exogeneity Wald Test

In this causality test will describe the causal relationship, namely changes in variables that are more influential on other variables. This causality test will produce whether the relationship of these variables is unidirectional (one-way) or bidirectional (two-way). In accordance with the results of causality test in table 3, there is merely a unidirectional relationship or a one-way relationship between the variables of the study at the significance of $5 \%$ and $10 \%$. The unidirectional relationship at the significance of $5 \%$ includes that of gold and crude oil (0.0005), gold and exchange rate (0.0406), and crude oil and GDP (0.0053). Meanwhile, the unidirectional relationship at the significance of $10 \%$ only occurs in GDP and Gold with a value of 0.0984 . The results of the causality test confirm the hypothesis that there is causality relationship between the variables of the study. In this study, there are only unidirectional relationships. Thus, this study concluded that there is a shortterm relationship between merely a few variables in the period 1999 to 2018. 


\section{Conclusion and Recommendations}

This study aims to discover the possibility of a long-term relationship and causality among gold, crude oil, exchange rate and GDP in Indonesia. The cointegration test revealed a cointegration relationship between the variables of the study. Meanwhile, the causality test discovered a unidirectional causality from crude oil to GDP and GDP to gold. The unidirectional causality is strengthened by Toda Yamamoto modified Granger Causality test, discovering a causal relationship between crude oil and gold, exchange rate and gold, and GDP and crude oil.

The findings of this study can be utilized as reference for stakeholders, importers, exporters, the government, policy makers, retail investors, and others. The exporters and importers can utilize the findings to determine the relationship between currency values and crude oil as well as gold price. The investors can utilize the findings as reference in investing, considering the short and long-term influence of the movements in gold price and crude oil price globally, affecting the volatility of exchange rate. Our reason for investing in gold is because gold is one of the tools used to maintain wealth even more important in an economic environment where investors are faced with a declining US dollar and rising inflation. Thus, when inflation is experiencing an increase, the gold meal will usually be appreciated. When investors realize that their money is losing value, they will begin to position their investments in hard assets that have traditionally maintained their value. The reason gold has an influence on US Dollar currency fluctuations is because gold is valued in US dollars globally. Meanwhile for the policy makers and the government, the research aims for utilize the findings in designing and establishing monetary policies to maintain the value and conditions of the national currency and economy. The policy makers and government need to pay attention to the increase in the exchange rate will enable a higher level of economic growth. Especially in the exchange rate it is a variable that is very influential on the national trade balance. The exchange rate itself is a variable that is very influential on the national trade balance.

However, it should be noted that an increase in demand for crude oil shall affect the demand for US Dollar, consequently shall affect the exchange rate of the domestic currency against the US Dollar. Related to the value of the US Dollar, that is the price of gold prices denominated in dollars, therefore, fluctuations in the value of the dollar have a large on the price of gold. According to historical statistics in recent years, the price of gold and the exchange rate of the US dollar with a value of $80 \%$ negative. Lost, dollar falls, gold rises; the dollar goes up, gold falls. This is caused by the ups and downs representing the market against dollar assets. The dollar rises, investors buy dollar-denominated assets to make a profit; While the US dollar is down, most of the funds come out of dollar assets to buy gold to support and increase profits. When the dollar falls, the exchange rate of the euro, yen and other currencies rises, so the price of gold in Euros and the yen are relatively cheap on the domestic gold market, which attracts investors to buy. This capital flow naturally drives up the price of gold.

Reference

[1] A. a. M. S. Shiva, "Understanding Dyanamic Relationship among Gold Price, Exchange Rate and Stock Markets: Evidence in Indian Context," Global Business Review, vol. 16 (5S), pp. 93S-111S, 2015.

[2] C. A. Sims, Macroeconomics and Reality. Econometrica, 1980.

[3] N. P. a. S. S. Singh, "Phase-wise analysis of dynamic relationship among gold, crude oil, US dollar and stock market," Journal of Advances in Management Research, vol. 15, no. 4, pp. 480-499, 2018.

[4] F. D. d. B. Y. Saragih, Dasar-Dasar Keuangan Internasional, Depok: Rajawali, 2014.

[5] M. a. A. B. R. Arfaoui, "Oil, gold, US dollar and stock market interdependencies: a global analytical insight," European Journal of Management and Business Economics, vol. 26, no. 3, pp. 278-293, 2017.

[6] M. Fahreza, "Analysis of Cointegration and Causality Relationship Between Gold Prices, World Oil Prices, The Rupiah Exchange Rate, and The Composite Share Price Index (IHSG) for The 2007-2016 Period," Global and Stochastic Analysis (GSA), vol. 5, no. 8, pp. 439-453, 2018.

[7] C. M. a. A. N. Singarimbuan, "The Relationship among Oli Prices, Gold Prices, Gross Domestic Product, and Interest Rate to the Stock Market Return of Basic Industry and Chemical Sector in Indonesia in 20052013," Journal Business and Mangement, vol. 3, no. 4, pp. 401-409, 2014. 
[8] D. N. d. D. C. P. Gujarati, Basic Economic 5th Edition, USA: MCGrawl-Hill, 2009.

[9] H. A. d. H. B. Chamalwa, "A Vector Autoregressive

\section{Bibliography}

[1] A. a. M. S. Shiva, "Understanding Dyanamic Relationship among Gold Price, Exchange Rate and Stock Markets: Evidence in Indian Context," Global Business Review, vol. 16 (5S), pp. 93S-111S, 2015.

[2] C. A. Sims, Macroeconomics and Reality. Econometrica, 1980.

[3] W. G. Council, World Gold Council, 2009. [Online]. Available: https://www.gold.org/aboutgold/gold-demand/sectors-of-demand. [Accessed 14 February 2019].

[4] N. P. a. S. S. Singh, "Phase-wise analysis of dynamic relationship among gold, crude oil, US dollar and stock market," Journal of Advances in Management Research, vol. 15, no. 4, pp. 480-499, 2018.

[5] F. D. d. B. Y. Saragih, Dasar-Dasar Keuangan Internasional, Depok: Rajawali, 2014.

[6] M. a. A. B. R. Arfaoui, "Oil, gold, US dollar and stock market interdependencies: a global analytical insight," European Journal of Management and Business Economics, vol. 26, no. 3, pp. 278-293, 2017.

[7] M. Fahreza, "Analysis of Cointegration and Causality Relationship Between Gold Prices, World Oil Prices, The Rupiah Exchange Rate, and The Composite Share Price Index (IHSG) for The 2007-2016 Period," Global and Stochastic Analysis (GSA), vol. 5, no. 8, pp. 439-453, 2018.

[8] C. M. a. A. N. Singarimbuan, "The Relationship among Oli Prices, Gold Prices, Gross Domestic Product, and Interest Rate to the Stock Market Return of Basic Industry and Chemical Sector in Indonesia in 2005-2013," Journal Business and Mangement, vol. 3, no. 4, pp. 401-409, 2014.

[9] D. N. d. D. C. P. Gujarati, Basic Economic 5th Edition, USA: MCGrawl-Hill, 2009.

[10] H. Y. a. T. Y. Toda, "Statistical inferences in vector autoregressions with possibly integrated processes," Journal of Econometrics, Vols. 66 Nos 1-2, pp. 225-251, 1995.

[11] H. A. d. H. B. Chamalwa, "A Vector Autoregressive (VAR) Cointegration and Vector Error Correction Model (VECM) Approach for Financial Deepening Indicators AND Economic Growth in Nigeria," American Journal of Mathematical Analysis, vol. 4, pp. 1-6, 2016.

[12] B. Chris, Introductory Econometrics for Finance, 2nd Edition, UK: Cambridge University Press, 2008. 
(VAR) Cointegration and Vector Error Correction Model (VECM) Approach for Financial Deepening Indicators AND Economic Growth in Nigeria," American Journal of Mathematical Analysis, vol. 4, pp. 16, 2016.

\section{Appendix}

Table 3. VEC Granger Causality/Block Exogeneity Wald Test in Lag 3

\begin{tabular}{|c|c|c|c|c|c|}
\hline Null Hypothesis: & Obs & F-Statistic & Prob. & Results & Causality \\
\hline $\begin{array}{l}\text { DOlL does not Granger Cause DGOLD } \\
\text { DGOLD does not Granger Cause DOIL }\end{array}$ & 76 & $\begin{array}{l}0.98395 \\
6.76449 \\
\end{array}$ & $\begin{array}{l}0.4055 \\
0.0005^{* *}\end{array}$ & $\begin{array}{l}\text { Accepted } \\
\text { Rejected }\end{array}$ & $\begin{array}{l}\text { No Causality } \\
\text { Uni Directional }\end{array}$ \\
\hline $\begin{array}{l}\text { DKURS does not Grang } \\
\text { DGOLD does sot Grang }\end{array}$ & 76 & 0.57362 & 0.6343 & $\begin{array}{l}\text { Acceppted } \\
\text { Rejerted }\end{array}$ & $\begin{array}{l}\text { No Causality } \\
\text { Uni Directional }\end{array}$ \\
\hline D2PDB does not Gra & 75 & 2.17919 & $0.0984^{*}$ & Rejected & Uni Directional \\
\hline DGOLD does not Granger Cause D2PDB & & 0.13294 & 0.9401 & Accepted & No Causality \\
\hline $\begin{array}{l}\text { DKURS does not Granger Cause DOL } \\
\text { DOIL does not Granger Calse DKURS }\end{array}$ & 76 & $\frac{0.62229}{1.57279}$ & 0.6030 & $\begin{array}{l}\text { Accepted } \\
\text { Accepted }\end{array}$ & $\begin{array}{l}\text { No Causality } \\
\text { No Causality }\end{array}$ \\
\hline $\begin{array}{l}\text { D2PDB does not Granger Cause DOLL } \\
\text { DOIL does not Granger Cause D2PDB }\end{array}$ & 75 & $\frac{1.53654}{4.61955}$ & $\frac{0.2130}{0.0053^{* *}}$ & $\begin{array}{l}\text { Accepted } \\
\text { Rejected }\end{array}$ & $\begin{array}{l}\text { No Causality } \\
\text { Uni Directional }\end{array}$ \\
\hline D2PDE & 75 & 0.62225 & 0.6030 & Accepted & No Casuality \\
\hline DKURS does not Granger Cause I & & 1.99548 & 0.1229 & & No Causality \\
\hline
\end{tabular}

Source: E-views 9 